\title{
Prospective study on effect of Helicobacter pylori on gastroesophageal
} reflux disease

Abstract
Background and objective: The Helicobacter pylori infections role in etiology of peptic

Background and objective: The Helicobacter pylori infections role in etiology of peptic ulcer is well known, but its role in gastroesophageal reflux disease is one of the important issues which has to be confirmed. We tried to find out the effect of Helicobacter pylori infection on gastroesophageal reflux disease.

Methods: The current study was done on 100 patients with gastroesophageal reflux disease from January $1^{\text {st }}$ to June $30^{\text {th }}, 2014$ in Rizgary Teaching Hospital, Erbil city. The diagnosis was made by history, clinical examination, and endoscopy. Helicobacter pylori infection was confirmed by gastric biopsy and histopathological examination. We tried to find out the effects of Helicobacter pylori infection in gastroesophageal reflux disease patients and its eradication on their symptoms. The data was analyzed with the statistical package for the social sciences (version 18).

Results: The mean age \pm SD of participants was $37.13 \pm 12.5$ (17-75 years). The prevalence of Helicobacter pylori infection was $75 \%$. The endoscopy showed that 50 out of 75 patients had erosive esophagitis and 25 out of 75 patients had normal appearance known as non-erosive esophagitis. The study showed no significance of its eradication on symptoms of gastroesophageal reflux disease.

Conclusion: The effect of Helicobacter pylori infection in gastroesophageal reflux disease patients was significant regarding endoscopic finding while inversely related to symptoms severity. The eradication of infection did not cause improvement in symptom severity i.e. triple therapy not advised in the course of treatment.

Keywords: Gastroesophageal reflux disease, Helicobacter pylori infection, Symptom severity; Endoscopic finding.

\section{Introduction}

Gastroesophageal reflux disease (GERD) defined as a reflux of gastroduodenal contents to esophagus causing troublesome symptoms and or mucosal injury. ${ }^{1}$ The main causes of GERD are secondary to permanent laxity of the collar sling musculature in the lower end of esophagus known as lower esophageal sphincter (LES), with a resultant distension of the gastric cardia and loss of the high-pressure zone in this sphincter. ${ }^{2}$ The cardinal symptoms are heartburn and acid regurgitation, others present with atypical symptoms like chest pain, asthma, laryngitis. ${ }^{2}$ Multiple factors were reported to affect on GERD pathophysiology such as age, gender, ${ }^{3,4}$ body mass index (BMI), ${ }^{5}$ alcohol drinking and smoking. ${ }^{3,4}$ Evaluation of stomach for motility and histology is necessary. Since reflux of gastric acid is the main factor in etiology of GERD. It is well known that chronic Helicobacter pylori $(H$. pylori) infection leads to gastric atrophy, which leads to decrease in gastric acid secretion. ${ }^{6,7}$ Probably reflecting a protective mechanism through hypoacidity accompanied with atrophic changes of gastric mucosa. The presence of $H$. pylori infection has been reported to be one of the protective factors for GERD. ${ }^{8-10}$ Although the prevalence of Helicobacter pylori is steadily decreasing

* Department of Surgery, College of Medicine, Hawler Medical University, Erbil, I raq. 
industrialized nations, while gastroesophageal reflux disease (GERD) and its complications are increasing. ${ }^{11}$ Most studies find no relation between $H$ pylori infection and etiology of GERD. ${ }^{12}$ While other studies have found a lower prevalence of $H$ pylori infection in patients with reflux symptoms, suggesting a possible protective effect of this bacterial infection. ${ }^{13}$ The relation between $\mathrm{H}$ pylori infection and GERD needs more study in order to find the effect of $\mathrm{H}$ pylori on GERD patients. It seems to be due to its effect on acid secretion from the stomach. One of the studies found a marked increase in acid secretion following $H$ pylori eradication in patients who developed erosive GORD. ${ }^{14}$ However, other studies didn't agree with this result. This study aimed to find out the effect $\mathrm{H}$ pylori infection on GERD patients symptom severity and endoscopic changes and treatments.

\section{Methods}

This study was done in Rizgary Teaching Hospital in Erbil city. One hundred GERD patients from January $1^{\text {st }}$ to June $30^{\text {th }}, 2014$ were included their ages between (17-75) years; $55 \%$ were female, and $45 \%$ were male patients. Details of investigations were explained. The study was approved by the Research Ethics Committee, College of Medicine, Hawler Medical University. The criteria of patients selection depended on full history taking and thorough clinical examination with endoscopy and biopsy taking, those presented with typical symptoms of reflux, like heartburn and acid regurgitation, were selected. Oesophago gastro duodenoscopy was explained and verbal consent taken from all patients before the procedure. Endoscopy was done under the local anesthesia (xylocaine) spray to the oropharynx. For patients who could not tolerate the procedure midazolam $5 \mathrm{mg}$ slow iv injection used, the endoscopic findings were classified to erosive esophagitis and non-erosive reflux disease (NERD). A biopsy was taken from the antral area of the stomach and send for histopathology to confirm $\mathrm{H}$ pylori infection. Serum lipase and amylase were done for all patients to exclude pancreatic problem and ultrasound of abdomen to exclude gall bladder disease and ECG done for those above 40 years to exclude cardiac disease. Other findings like peptic ulcer and gastric cancer were excluded from the study. The positive $\mathrm{H}$ pylori test treated with (oral clarithromycin 500mg every 12 hour and oral Amoxicillin 1gm every 12 hour and oral lansoprazole $30 \mathrm{mg}$ every 12 hours for 14 days) its eradication was confirmed by the absence of $\mathrm{H}$ pylori $\mathrm{Ag}$ in the stool. Ten patients needed the second dose of treatment for their eradication. After two weeks patients were asked about their symptoms and the results were recorded. The symptoms were classified to mild with one attack of heartburn per week and severe with five or more attacks per week.

\section{Results}

The 100 patients were included for statistical analysis, 45\% male and 55\% female, the mean age \pm SD of participants was $37.13 \pm 12.5$ range (17-75) years. Regarding the relation of $\mathrm{H}$ pylori infection with endoscopic finding, $75 \%$ were $\mathrm{H}$ pylori test positive and $25 \%$ were negative. From those who had a positive test, $42.7 \%$ showed erosive esophagitis with lax sphincter and hiatal hernia. Of those who had negative $\mathrm{H}$ pylori test, $24 \%$ showed same endoscopic findings (erosive esophagitis with lax sphincter and hiatal hernia). $23 \%$ of $\mathrm{H}$ pylori positive patients and $20 \%$ of $\mathrm{H}$ pylori-negative patients had a normal endoscopy, as shown in Table 1. This study showed a statistically significant relation between symptom severity and $\mathrm{H}$ pylori infection, $P=0.033$. Seven patients $(9.3 \%)$ with $\mathrm{H}$ pylori positive had one heartburn attack per week, and two patients $(8 \%)$ with $\mathrm{H}$ pylori test negative had one attack per week. While twenty patients (26.7\%) with $\mathrm{H}$ pylori positive had five attacks per week, fifteen patients 
(60\%) with $\mathrm{H}$ Pylori test negative had five to treatment, while 13 (17.3\%) said attacks per week as shown in Table 2. Regarding the symptoms of patient after eradication of $\mathrm{H}$ pylori was insignificant; 50 out of 75 patients $(66.7 \%)$ of whom $\mathrm{H}$ pylori eradication showed no response their symptoms were decreased or even disappeared and $12(16 \%)$ of patients said their symptoms became worse, as shown in Table 3.

Table 1: Relation of endoscopic finding with $\mathrm{H}$ pylori test

\begin{tabular}{lcccccccc}
\hline \multirow{2}{*}{ Endoscopic finding } & \multicolumn{3}{c}{ H pylori test } & & & \\
& \multicolumn{2}{c}{ Positive } & \multicolumn{2}{c}{ Negative } & \multicolumn{2}{c}{ Total } & \multicolumn{2}{c}{$\boldsymbol{P}$ value } \\
& No. & $\%$ & No. & $\%$ & No. & $\%$ & \\
\hline Lax sphincter+errosive esophagitis & 12 & 16.0 & 2 & 8.0 & 14 & 14.0 & \\
Hiatus hernia+lax sphincter+esophagagitis & 32 & 42.7 & 6 & 24.0 & 38 & 38.0 & \\
Normal looking esophagus+lax sphincter & 14 & 18.7 & 12 & 48.0 & 26 & 26.0 & 0.031 \\
Normal & 17 & 22.7 & 5 & 20.0 & 22 & 22.0 & \\
Total & 75 & 100.0 & 25 & 100.0 & 100 & 100.0 & \\
\hline
\end{tabular}

Table 2: Relation between heartburn frequencies to $\mathrm{H}$ pylori test

\begin{tabular}{|c|c|c|c|c|c|c|c|c|c|c|c|c|}
\hline \multirow{3}{*}{ H Pylori } & \multicolumn{10}{|c|}{ No. of Heartburn attacks } & \multirow[t]{3}{*}{$\mathbf{N}$} & \multirow{3}{*}{$P$ value } \\
\hline & \multicolumn{2}{|c|}{1.00} & \multicolumn{2}{|c|}{2.00} & \multicolumn{2}{|c|}{3.00} & \multicolumn{2}{|c|}{4.00} & \multicolumn{2}{|c|}{5.00} & & \\
\hline & No. & $\%$ & No. & $\%$ & No. & $\%$ & No. & $\%$ & No. & $\%$ & & \\
\hline Positive & 7 & 9.3 & 22 & 29.3 & 18 & 24.0 & 8 & 10.7 & 20 & 26.7 & 75 & \\
\hline Negative & 2 & 8.0 & 4 & 16.0 & 4 & 16.0 & 0 & 0.0 & 15 & 60.0 & 25 & 0.033 \\
\hline Total & 9 & 9.0 & 26 & 26.0 & 22 & 22.0 & 8 & 8.0 & 35 & 35.0 & 100 & \\
\hline
\end{tabular}

Table 3: Response to treatment by symptoms after eradication of H Pylori.

\begin{tabular}{|c|c|c|c|c|c|c|c|c|c|c|c|}
\hline \multirow{3}{*}{$\begin{array}{l}\text { Symptoms } \\
\text { after H pylori } \\
\text { eradication }\end{array}$} & \multicolumn{8}{|c|}{ Endoscopic finding } & & & \multirow{3}{*}{$P$ value } \\
\hline & \multicolumn{2}{|c|}{$\begin{array}{c}\text { Lax } \\
\text { sphincter+ } \\
\text { erosive } \\
\text { esophagitis }\end{array}$} & \multicolumn{2}{|c|}{$\begin{array}{l}\text { Hiatus hernia+ } \\
\text { lax sphincter+ } \\
\text { esophagagitis }\end{array}$} & \multicolumn{2}{|c|}{$\begin{array}{c}\text { Normal looking } \\
\text { esophagus+ } \\
\text { Lax sphincter }\end{array}$} & \multicolumn{2}{|c|}{ normal } & \multicolumn{2}{|c|}{ Total } & \\
\hline & No. & $\%$ & No. & $\%$ & No. & $\%$ & No. & $\%$ & No. & $\%$ & \\
\hline $\begin{array}{l}\text { Decreased or } \\
\text { disappeared }\end{array}$ & 1 & 8.3 & 5 & 15.6 & 4 & 28.6 & 3 & 17.6 & 13 & 17.3 & \\
\hline Increased & 2 & 16.7 & 5 & 15.6 & 4 & 28.6 & 1 & 5.9 & 12 & 16.0 & 1450 \\
\hline No response & 9 & 75.0 & 22 & 68.8 & 6 & 42.9 & 13 & 76.5 & 50 & 66.7 & \\
\hline Total & 12 & 100.0 & 32 & 100.0 & 14 & 100.0 & 17 & 100.0 & 75 & 100.0 & \\
\hline
\end{tabular}




\section{Discussion}

Since the discovery of Helicobacter pylori two decades ago, it has become increasingly obvious that there are relationships between this organism and diseases of the upper gastrointestinal tract. The role of $\mathrm{H}$. pylori infection in GERD is still controversial and incompletely understood. In the current study, the incidence of erosive esophagitis was higher in $\mathrm{H}$ pylori infected patients than non -infected ones. This might be due to the fact that the prevalence of infection is higher than noninfection, or due to the fact that $H$ pylori infection leads to increase acid production leading to increasing acid exposure to the esophagus. ${ }^{15}$ This bacteria has a bimodal effect on acid secretion from the stomach, antral predominant inflammation or corpus predominant inflammation. ${ }^{15}$ In Non-atrophic predominantly antral inflammation there is hypergastrinemia and acid hypersecretion, so their effects will increase acid exposure to esophagus resulting in erosive esophagitis. In contrast, patients with predominantly atrophic corpus gastritis will have decreased acid secretion with a protective effect on esophagus ${ }^{16}$. The incidence of erosive esophagitis is more in infected than noninfected patients. And this was consistent with a study done by Lijima et al. in Japan. ${ }^{1}$ Regarding the relation between $\mathrm{H}$ pylori infection and symptom severity, the noninfected group had more frequent attacks than infected ones. This is due to decrease in acid secretion in that predominantly atrophic corpus gastritis. ${ }^{16}$ Regarding the effect of $\mathrm{H}$ pylori eradication on symptoms of GERD patient's majority of patients $(66.7 \%)$ had no response to eradication (50 patients out of 75 patients), while $(16 \%)$ of patients had their symptoms increased and (17.3\%) decreased and even disappeared. This indicates that there is no role of $\mathrm{H}$ pylori eradication on GERD patients' treatments. This is consistent with a study done in Japan which also stated that eradication of $\mathrm{H}$ pylori has no significant effect on GERD treatment. ${ }^{18}$

\section{Conclusion}

$\mathrm{H}$ pylori infection is not confirmed to be the etiology of reflux in GERD patient, but it can affect in one way or another on the symptoms of GERD by its effect on acid secretion. Its eradication has no effect on the treatment of GERD. The study cannot advise triple therapy in the treatment of GERD.

\section{Conflicts of interest}

The author reports no conflicts of interest.

\section{References}

1. Vakil N, van Zanten SV, Kahrilas P, Dent J, Jones $\mathrm{R}$, et al. The Montreal definition and classification of gastro esophageal reflux disease: a global evidence-based consensus. Am J Gastroenterology 2006;101(8): 1900-20;

2. Jobe BA, Hunter JG, Watson DI. Esophagus and diaphragmatic hernia. In: Brunicardi $F$, Andersen D, Billiar T, Dunn D, Hunter J, Matthews J, (editors). Schwartz's Principles of Surgery, $10^{\text {th }}$ ed. New York: Mc Graw-Hill; 2015. P. 966.

3. Dent J, El-Serag HB, Wallander MA, Johansson S. Epidemiology of gastroesophageal reflux disease: a systematic review. Gut 2005;54(5): 710-7. doi: 10.1136/gut.2004.051821

4. Moayyedi P, Talley NJ. Gastro-esophageal reflux disease. Lancet 2006; 367(9528): 2086-100. doi: 10.1016/s0140-6736(06)68932-0

5. Jacobson BC, Somers SC, Fuchs CS, Kelly CP, Camargo CA. Body-mass index and symptoms of gastroesophageal reflux in women. $\mathrm{N}$ Engle $\mathrm{J}$ Med 2006; 354(22): 2340-8. doi: 10.1056/ nejmoa054391

6. El-Omar EM, Oien K, El-Nujumi A, Gillen D, Wirz A, Dahill S, et al. Helicobacter pylori infection and chronic gastric acid hyposecretion. Gastroenterology 1997; 113(1): 15-24. doi: 10.1016/s0016-5085(97)70075-1

7. Miwa $\mathrm{H}$, Go MF, Sato $\mathrm{N} \mathrm{H}$. pylori, and gastric cancer: the Asian enigma. Am J Gastroenterology 2002; 97(5): 110612.

8. Fujiwara $Y$, Arakawa T. Epidemiology and clinical characteristics of GERD in the Japanese population. J Gastroenterol 2009;44(6): 518-34. doi: 10.1007/s00535-009-0047-5.

9. Koike T, Ohara S, Sekine H, lijima K, Abe Y, Kafo $\mathrm{K}$, et al. Helicobacter pylori infection prevents erosive reflux oesophagitis by decreasing gastric acid secretion. Gut 2001;49(3): 330-4. doi: 10.1136/gut.49.3.33

10. El Serag HB, Sonnenberg A. Opposing time trends of peptic ulcer and reflux disease. Gut1998; 43:327-33. [Pub Med]. 
11. Richter JE, Falk GW, Vaezi MF. Helicobacter pylori and GERD: the bug may not be all bad. Am J Gastroenterol 1998;93:1800-2.

12. Loffeld RJ, Werdmuller BF, Kuster JG, Perez GI, Blaser MJ, Kupers EJ, et al. Colonization with cag A positive Helicobacter pylori strains inversely associated with reflux esophagitis and Barrett's esophagus. Digestion 2000;62:95-9.

13. Hamada $H$, Haruma $K$, Mihara $M$, Kamada $\mathrm{T}$,Yoshihara M,Sumii K,et al. High incidence of reflux oesophagitis after eradication therapy for Helicobacter pylori: impacts of a hiatal hernia and corpus gastritis.Aliment Pharmacol Ther 2000;14:729-35.

14. Labenz J, Malfertheiner P. Helicobacter pylori in gastro-esophageal reflux disease: causal agent, independent or protective factor? Gut 1997; 41:277-815

15. Richter JE. The Cleveland Clinic Effect of Helicobacter pylori eradication on the treatment of gastro-esophageal reflux disease Gut. 2004 ; 53(2): 310-11.

16. lijima K, Sekine H, Koike T, Imatani A, Ohara S, Shimosegawa T. Long-term effect of Helicobacter pylori eradication on the reversibility of acid secretion in profound hypochlorhydria. Aliment Pharmacol Ther 2004;19:1181-8. 10.1111/j.1365-2036.2004.01948.x

17. Fukuchi T. Influence of cure of Helicobacter pylori infection on gastric acidity and gastroesophageal reflux: a study by $24-\mathrm{h} \mathrm{pH}$ monitoring in patients with gastric or duodenal ulcer. J Gastroenterology 2005; 40(4):350-60. 